\title{
Fusion of time and space in Hans Roosenschoon's music: A pre-analytical strategy
}

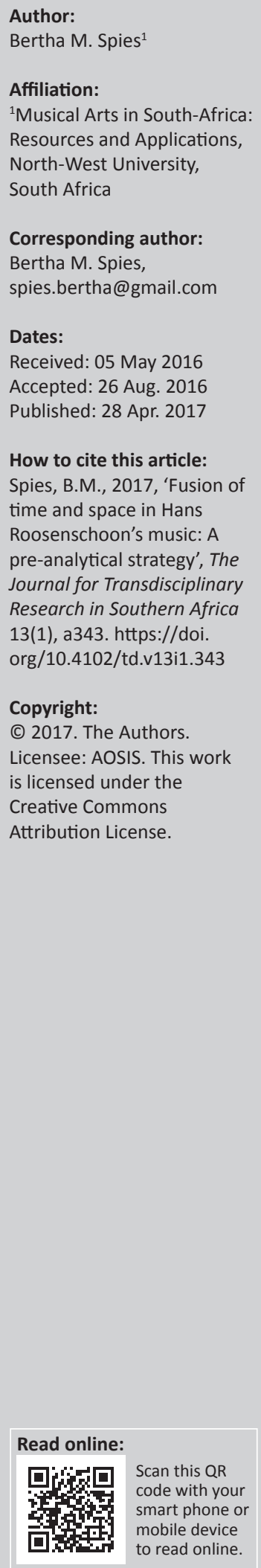

In order to promote access to non-tonal music, the fusion of musical time and space may be considered as a point of departure. As a pre-analytical strategy, it relies on direct experience of the music as it is heard instead of on specialised music theoretical knowledge. The music of Hans Roosenschoon is used to illustrate five ways in which the fusion of time and space manifests itself on a metaphorical level, namely the integration of Western and African cultural spaces through music as a temporal art form, the blending of time and space in the music itself and the fusion of art music from the past with everyday life by electronic means. A true story from the South African past that combines with a visual image associated with Cape Town represents another version of fusing time and space, while on a metaphysical level past and present coalesce as melodic references to Schubert's music are used to signify abstract ideas. Listening to music directly rather than through the filter of a rational analytical system helps to develop an appreciation of non-tonal music, a kind of music that is often regarded as inaccessible.

\section{Introduction}

Does beauty lead to wisdom, Phaedrus? Yes, but through the senses. (Britten 1973)

With these words the celebrated writer Gustav von Aschenbach begins his Phaedrus monologue in Benjamin Britten's Death in Venice, an opera based on Thomas Mann's novella. Von Aschenbach's monologue refers to Plato's dialogue between Socrates and one of his young admirers, Phaedrus. In the novella, the writer 'is caught between Apollonian order and Dionysian licence' (Spies 2002:8). The conflict in his mind is portrayed by the combination of sound (musical and otherwise) and visual images when Britten's music accompanies picturesque shots of von Aschenbach's gondola trip to Venice in Tony Palmer's film version of Britten's opera (2012). The effect of moving images combined with music could be perceived as a kind of communication without words, of 'speaking' through the senses. On a subjective level, perceivers could interpret the message in various ways. But on a more concrete level this filmic version of von Aschenbach's trip to Venice signifies in a dualistic way (reflecting his mind vacillating between the rational and the intuitive) the contrast between the impressive architectural structures, sometimes faintly visible through the enveloping mist, and the sound of water splashing against the gondola, the play of light on dark water and the sound of church bells (this excerpt of the film is available at https://www. youtube.com/watch?v=gOqGcTRwzQw).

In another article I used the direct communication between a visual image and the viewer as the basis for my search for understanding 'the interaction between two different cultures' (Spies 2016:32). ${ }^{1}$ I argued that the direct experience of melodic motifs can facilitate this project because '[ $m$ ] usic is still the most immediate of all aesthetic experiences' (Kramer 1995:18) and, specifically, melodic contours 'speak' directly to the listener 'without first having been subject to systematisation', a strategy that is typical of musical analysis (Spies 2011:188). In their discussion of 'understanding in [the listener's] response versus understanding through analysis', Koopman and Davies (2001) differentiate between understanding 'a work from the inside' and analytical strategies that 'approach music from the outside, that is as an artefact put together in an ordered way' (267-268).

Anchored in 18th-century Cartesian thought (Christensen 1993), music theory as a discipline is, generally speaking, more concerned with rational operations than with the aesthetic experience of music as sound. This article aims to counter the traditional distrust of the senses by demonstrating that, specifically, sound (hearing and listening) and sight (seeing) can also facilitate access to 1.Two photos of the first performance of Peter Klatzow's Words from a broken string provided the basis for my argument in the last article. 
non-tonal music, a kind of music that is often regarded as difficult to understand. In order to promote the direct experience of music, this article provides links to audio files on YouTube.

Music is generally regarded as a temporal art form, but in spite of the 850 articles and books that deal with time and music listed in 1985, 'musical time is not usually considered a subject of music theory at all' (Kramer 1988:2). Although the issue of musical space 'is a problem that has long concerned aestheticians' (Morgan 1980:528), even less has been written about the spatial nature of music. More specifically, Susan McClary state that 'American musicology and music theory have rarely been interested in examining the temporal and spatial dimension of music per se' (1989-1990:107). It seems as if the situation has not changed much because musical time and space still do not figure in the article on analysis in Grove music online (Bent \& Pople 2007-2016). ${ }^{2}$

The focus on musical time and space could be regarded as an approach that relies more on direct experience of the music and less on specialised music theoretical knowledge. It is therefore a pre-analytical strategy because it takes as its point of departure the music as it is heard - even an untrained person can hear when a sound is high or low, or when it goes up or down. Small or big leaps, blocks of sound, thick or thin lines that move through space, with or without trills or smooth undulations such as tremolos, are also easily identifiable. Indeed, Eero Tarasti (1994) asks:

What else does a musical composition offer us but song lines, paths, routes we take through musical space? ... Listening to a composition is like journeying through this imaginary space. (p. 78)

As music moves through structured space, '[m] usical space is thus inseparable from musical time, just as musical time is inseparable from musical space. ... Musical space is the framework within which, and through which, the actual sequence of musical events is shaped. ... [T] he notion of musical space seems especially appropriate to much recent music' (Morgan 1980:529, 533). If the fusion of musical time and space is the point of departure in the pursuit of understanding non-tonal music, it could add a new dimension to existing systems of analysis. In this article, the notions of time and space are extended metaphorically because metaphor creates 'new modes of representing or describing reality' (Kassler 1991:xi). ${ }^{3}$

With regard to musical space more specifically, in non-tonal music the notion of duration is not only restricted to note values, but it could be extended to include blocks of sound that are prolonged to create sound bands of various lengths and various thicknesses. What is more, these blocks or bands

2.The online version of The new Grove dictionary of music and musicians gives $2007-$ 2016 as the copyright date because it is 'updated three times a year' (http://www. oxfordmusiconline.com).

3.This article does not deal with notational space (graphic representation of the score), physical performance space and 'spatial' music that refers to the position of speakers. of sound can also have various textures (brittle, pizzicato, porous, solid or smooth), or they can have flat surfaces created by sustained notes or chords, repeated notes or chords, repeated melodic or rhythmic patterns.

Blocks or bands of sound are part of the three-dimensional model of tonal space that Hans Roosenschoon started working on when he was a student in London in the 1970s (pers. comm., 03 September 2015), a model that he still uses in his teaching at Stellenbosch University (Roosenschoon 2015). Figure 1 shows his drawing of ways in which pitches combine to form various kinds of sound bands.

Dynamics and articulation also create the illusion of musical space - in Figure 2 the sustained note in the first line, the squiggly patterns in the second and the isolated accents in the third line, respectively, represent the background, middle ground and foreground of musical space.

Figure 3 shows how the composer creates progression in music that does not rely on the functional harmonic structures of tonal music.

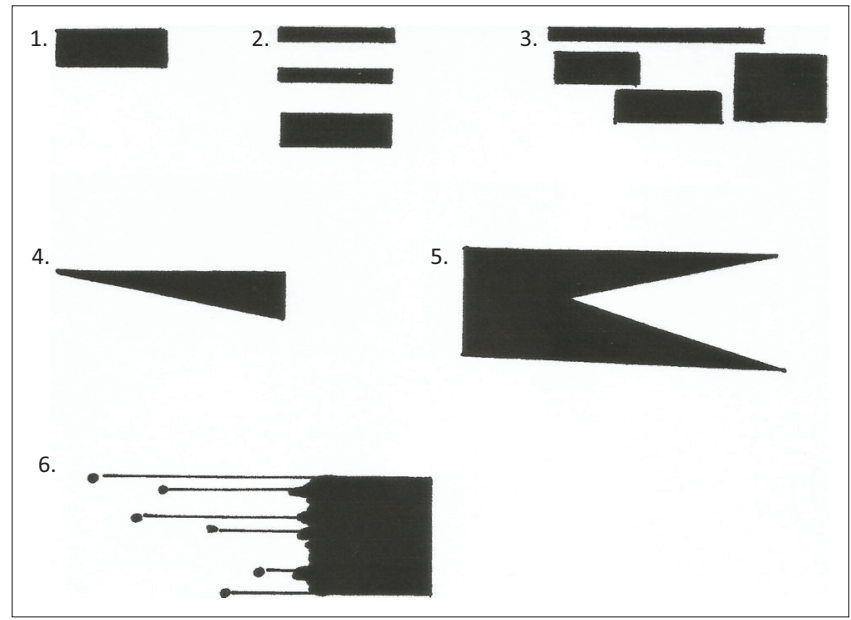

Source: Roosenschoon (2015)

FIGURE 1: The combination of pitches forms blocks or bands of sound.

\section{o}
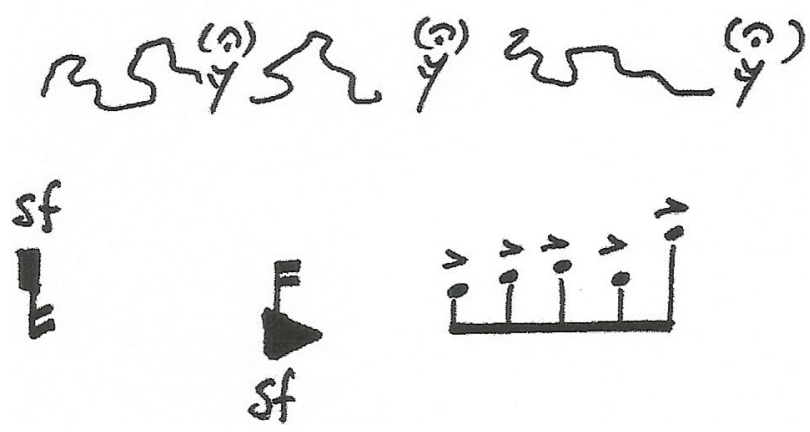

Source: Roosenschoon (2015)

FIGURE 2: Articulation and dynamics create levels of sound. 


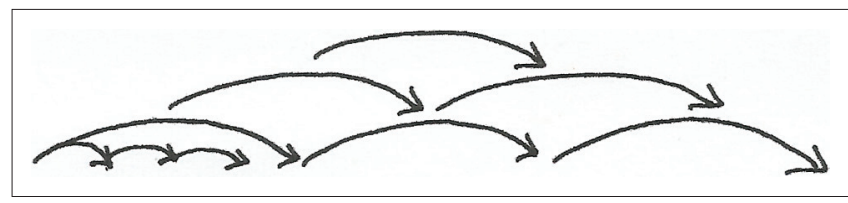

Source: Roosenschoon (2015)

FIGURE 3: Non-tonal means to produce progression.

A variety of dynamics (loud, soft, getting louder, getting softer), changes in density and increasing or decreasing impulses per beat also help to establish points of arrival in bands of sound. ${ }^{4}$ Creating points of arrival in this way has the same function as the harmonic progression that moves towards a cadence in tonal music. 'Variations in texture constitute one of the most important and readily observable features of musical development, and they produce an effect that is unmistakably "spatial" in quality' (Morgan 1980:528). Timbre, tone quality, articulation and tempo also influence the effect of sound as it travels through time. ${ }^{5}$

Analytical strategies normally include spatial concepts, but in my opinion they are not dealt with specifically as spatial phenomena. In the broadest terms, musical space entails the overall structure of the work, while smaller musical spaces involve movements, sections, phrases and motifs. Melodies, rhythmic patterns, ostinatos, repetitions, chords and intervals, whether horizontal (melodic) or vertical (harmonic), also occupy spaces.

\section{Roosenschoon defines stratified layers of sound}

as the vertical sound complex that changes from moment to moment as a result of the variable tone spectra and the varied dynamic impact of each individual moment. ... It is the shaping of this sound complex - horizontally distributed layers and vertically distributed sound splashes - and the instrumentation that such geometric constructs calls for that are such tremendous creative challenges for me. (Roosenschoon 2009)

Considering time and space as metaphors, I have chosen five topics to illustrate various ways in which Hans Roosenschoon fuses them in his music, including the integration of Western and African cultural spaces in music as a temporal form of art, the blending of time and space in the music itself, and the fusion of art music from the past with everyday life by electronic means. A true story from the South African past that combines with a visual image associated with Cape Town represents another version of fusing time and space, while on a metaphysical level past and present coalesce as melodic references to Schubert's music are used to signify abstract ideas.

\section{Music fuses Western and African cultural spaces}

Long before it was considered politically correct to incorporate indigenous African elements into Western musical space. music, Hans Roosenschoon composed Makietie for brass quintet (1978) while he was a student in London. The title of Makietie is of Zulu origin and the word itself is an informal Afrikaans expression for a celebration. But the composer based the work on melodic materials borrowed from the Xhosa song Qongqothwane, ${ }^{6}$ because ' $[t]$ he physical earthiness and the unspoilt nature of indigenous African music, with its boundless energy attract him' (Du Plessis 1989:43). Players are instructed to whistle the tune, exhale through their instruments, produce tongue clicks and stamp their feet to produce a mood of uninhibited and spontaneous celebration.

The song first appears almost as if out of focus, that is in $3 / 4$ time instead of the original 4/4 time (see Figure 4). Eventually the real Xhosa song crystallises towards the end of the work, but then not played by the instruments but whistled by the players. The fact that the original source of this work only appears later on in the work could be regarded as the music moving towards a point of arrival, or, as the composer later described the technique, as moving towards the origin (Muller 2002).

Qongqothwane begins with a descending major third interval (A-F) and the first four-bar phrase in Figure 4 ends with a descending minor third (F-D). The melodic contours in this Xhosa song are generally descending and the answering phrase ends with the last four pitches of the descending pentatonic scale (here A-G-F-D-C). By means of different kinds of variations the composer first explores the potential of the major third and after that the minor third to set up various kinds of textures and various kinds of layers. For example, from bar 31 (Figure 5) staggered entries of sustained notes on A and F played by the two trumpets, the horn and the trombone occur. The auxiliary note figure created by microtonal inflections on A and F (in contrary motion) first changes into a slow trill figure and then systematically increases its number of impulses per beat, creating the effect of movement through space. Later on in bar 118 (second system of Figure 5) staggered entries of variations of the descending major and minor third eventually form a sound band consisting of five layers (the fifth layer played by the tuba is not shown in Figure 5).

According to the South African composer Bongani NdodanaBreen, layered music is typical of African music. He also regards patterns that do not change, or patterns that grow in interaction with other patterns to change into new patterns, as typical of the music of the continent (in Van Rooyen 2013:3).

Spatial effects caused by the way in which pitch is organised in Makietie include tremolos on the major third (at b. 60) and the minor third (at b. 126), a repetitive pattern based on the descending pentatonic three-note motif ( $\mathrm{G}-\mathrm{F}-\mathrm{D}$ from b. 280) and the staggered entries of sustained notes from the pentatonic scale on $\mathrm{D}$ flat, introduced in descending 6.This song, known as the Click song, became famous through Miriam Makeba's performance. Listen on YouTube at https://www.youtube.com/watch?v=onBLru8SfOk 


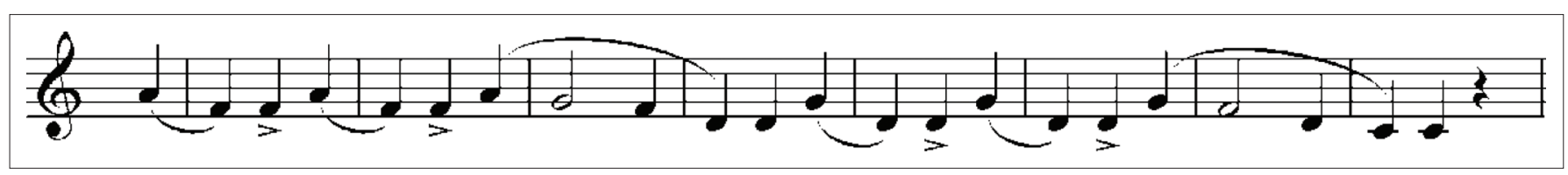

Source: Roosenschoon (1978)

FIGURE 4: Qongqothwane as quoted in bars $4^{3}-12$.

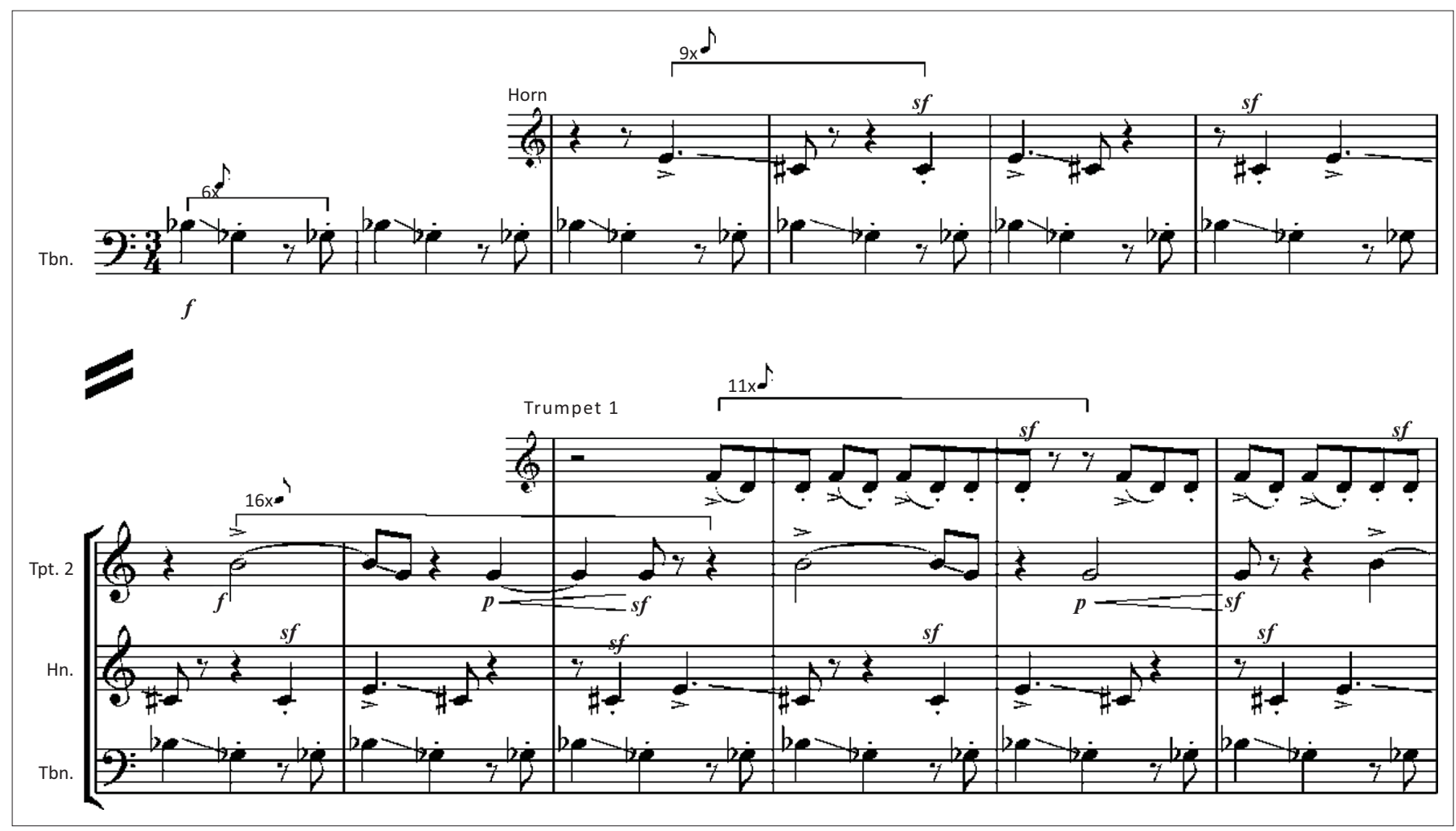

Source: Roosenschoon (1978)

FIGURE 5: Makietie, bands of sound consisting of repeated major and minor thirds.

order (bb. 489-493). The way in which time is organised also creates spatial effects. The systematic increase or decrease of the number of impulses per beat in asynchronic rhythmic patterns produces the effect of progression. (See Figure 5, also bars 98-116 and 151-186.) Considering the musical space as a whole, almost two-thirds through the piece (b. 316) the return of Qongqothwane as it is quoted in bars $4^{3}-12$ is prepared for by the repetition of the descending three-note pentatonic melodic pattern that is repeated for 16 bars (listen to Makietie on YouTube at https: / /youtu.be/dIEdZOvJckg). ${ }^{7}$

\section{Fusion of time and space in the music itself}

When the South African Broadcasting Corporation (SABC) invited Roosenschoon to compose a work that could be regarded as a 'signature' of his style, he took the request literally by using as point of departure a tone row of 14 notes derived from his name. Anagram (1983) is not strictly serial, however, but the set of notes determines the nature of vertical and horizontal structures. Although the composition reflects the principal characteristics of his style at the time, his later music turned out to be more accessible than this short five minute work with its strong modernist associations.

Controlled aleatory effects evoke Lutosławskian soundscapes $^{8}$ - a player or a group of players repeat a prescribed pattern until a specific moment has been reached. If such a fragment is followed by a straight line, 'the given fragment is to be repeated ad libitum a number of times and is abruptly stopped at the conductor's cue'. If the fragment is followed by a wavy line, it is repeated in the same manner, but then it 'is to be completed when the conductor's cue is given. ... When more than one player is required to play an identical fragment, their playing need not be synchronized' (according to the composer's instructions in the score).

The combination of layers creates prolonged bands of sound that fill the musical space. The nature of the 'musical filling', either in the form of sustained notes in the various parts, as unsynchronised trills and tremolos, as repeated patterns or as pointillist effects, results in thick or thin textures. When bands of sound systematically contract (for example, on pp. 5

8.See Spies (1994) for a discussion of controlled aleatory in the creation of sound bands in Lutosławski's string quartet. 


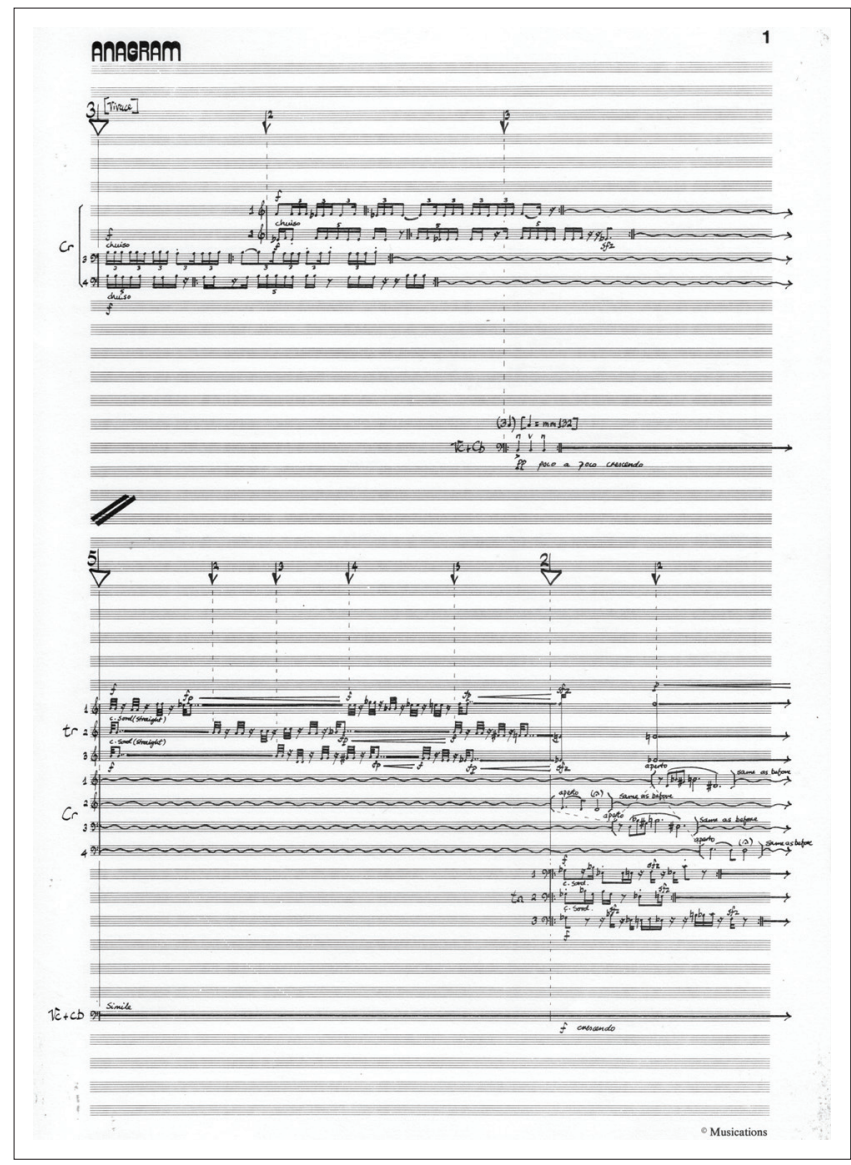

Source: Roosenschoon (1983)

FIGURE 6: Anagram, page 1.

and 6 of the score), they create points of arrival. Even when they are static, the change in dynamics (such as effected by crescendo and $s f$ ) creates the effect of progression, a typical spatial characteristic (Figure 6) (listen to Anagram on YouTube at https:/ / youtu.be/4_laCjlBJJc).

\section{Fusion of music from the past with everyday life}

Roosenschoon wrote If music be (1984), an electronic work for tape collage realised in a recording studio (1985), as 'a homage to the art of J.S. Bach. This tribute, however, is not in the form of an imitation of the Bach style; rather, a sound adventure' (Roosenschoon 1986b:109). Apart from the B-A$\mathrm{C}-\mathrm{H}$ motif, the bass line and short fragments from the Crucifixus of his Mass in B minor occur throughout the work and at some point these elements provide the basis for a pop song. Fragments of music by other composers, for example, Mozart (Eine kleine Nachtmusik) and Dvořák (New world symphony) are also quoted.

The title is taken from Shakespeare's Twelfth Night: 'If music be the food of love, play on!' Near the end of the work Roosenschoon (1986b) provides his own variation on the title:

If love of play be the food of music

If music feeds love's play

If play for food be loving music

If love of music be food for play

Then music be the food of love. (p. 109)
The music is written for a keyboard synthesizer, string ensemble, pop group and voices reciting a line. The introduction of familiar sound clippings taken from everyday environments creates experiences that range from the dramatic to the humorous and even the absurd. Spatial effects are again created by layers of sound and electronic sound masses. In section II a radio commentator reports on a horse race with the horses given the fictional names of If, Lover, Midsummer Night, The Duke, Musical, Exposition, Presto, Play on, Joker and Junk Food, with Play on announced as the winner. South African composer Chris James (1986:111) regards 'Roosenschoon's ability to draw on and integrate material from a wide variety of sources [as] remarkable and his instinctive feeling for drama and comic relief is noteworthy' (listen to If music be on YouTube at https://youtu.be/WJNfjyST-vU).

\section{Fusion of a South African story with a visual image}

The Cape Malay song about the arrival of a ship, Daar kom die Alibama (Here comes the Alabama), forms the basis of Architectura - A soundscape of Cape Town (1986a). During the American Civil War this raider from the southern states visited Cape Town harbour for provisions and repairs in 1863. The Alabama was met by a crowd of excited spectators and the result was the minstrel song, which is still sung during the New Year's celebrations of the Malay people of Cape Town (Stevens 2010) (the song is on YouTube at https: / / www.youtube.com/watch? $v=r B r o 7 d Q o 8 d c)$.

In minimalist fashion the first eight bars of the song are repeated over and over to portray the arrival and departure of the Alabama (Figure 7). At the beginning of the work the staggered entries in the style of a canon cause a systematic rise in pitch level. An increase in density is also linked with a systematic rise in dynamics at every level of entry. Beginning in the dark, lowest register of the double basses playing $p p$, one can hear and almost see in one's mind's eye the approach of the famous ship the Alabama, which comes from afar, and how it comes nearer and nearer to Cape Town's harbour. Similarly the opposite procedure, namely the systematic lowering of pitch levels, density and dynamics (from b. 292), depicts the Alabama leaving the harbour.

But this music could also represent a static picture and initially it reminded me - an idea most probably prompted by the title of the work - of the physical structure of a Dutch gable, which is such a prominent architectural feature in the Western Cape. After I had written the initial version of this article, I asked the composer whether he had this architectural design in mind when he wrote Architectura. He replied that he actually intended to portray Table Mountain, that famous landmark which appears on so many pictures of Cape Town (Figure 8). So I made a graphic representation of the work and it indeed turned out to look more like Table Mountain than the Dutch gable that I had in mind.

The first 92 bars and the final 94 could be heard as a relative representation of the upward and downward slope of 


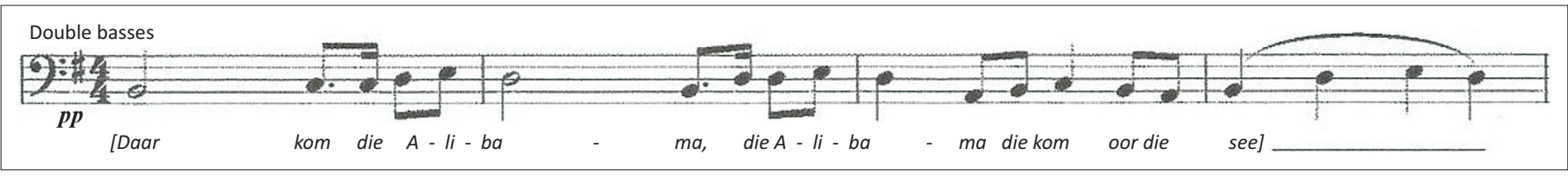

Source: Roosenschoon (1986a)

FIGURE 7: Architectura, bars 1-4 with the words of the Afrikaans song.

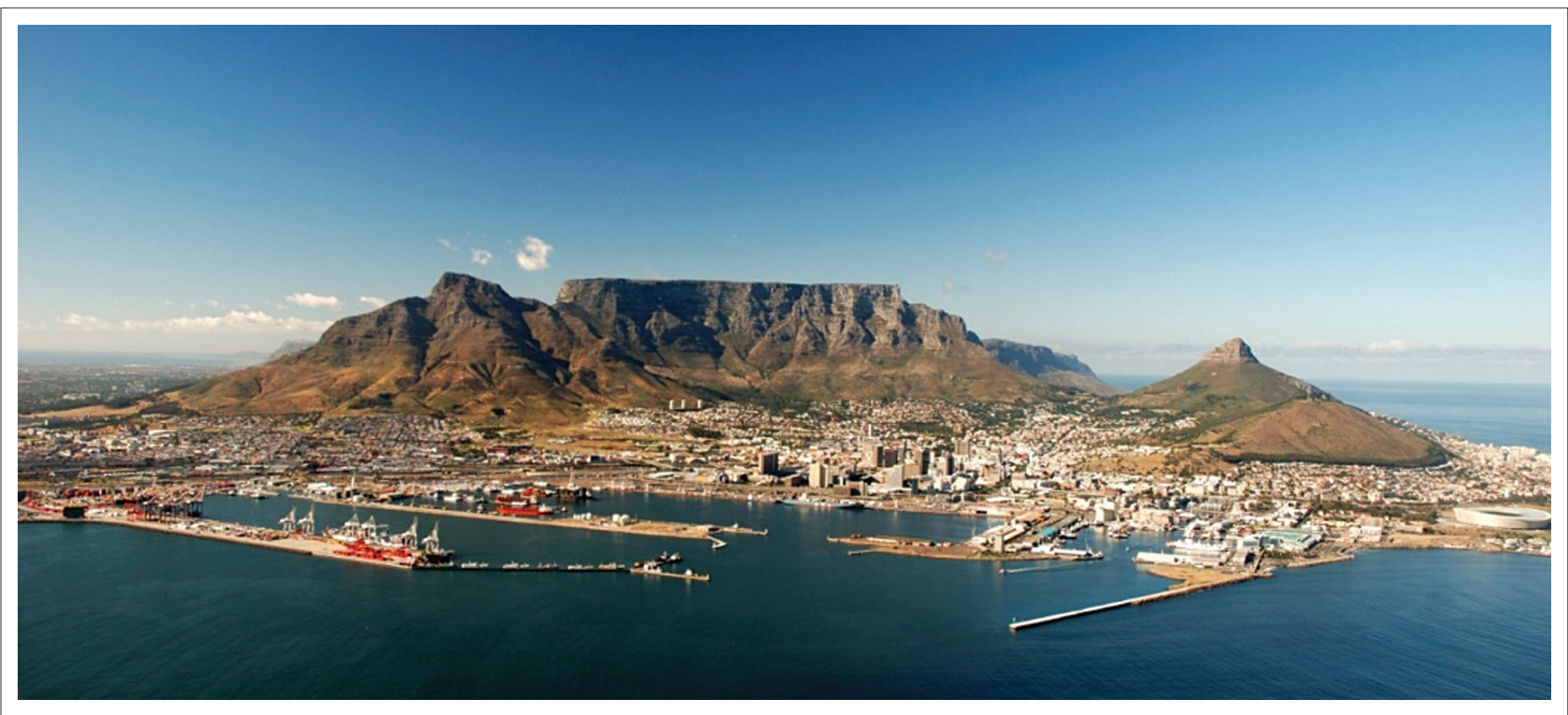

Source: https://www.google.co.za/search?q=Table+mountain+Cape\&biw

FIGURE 8: Table Mountain, Cape Town.

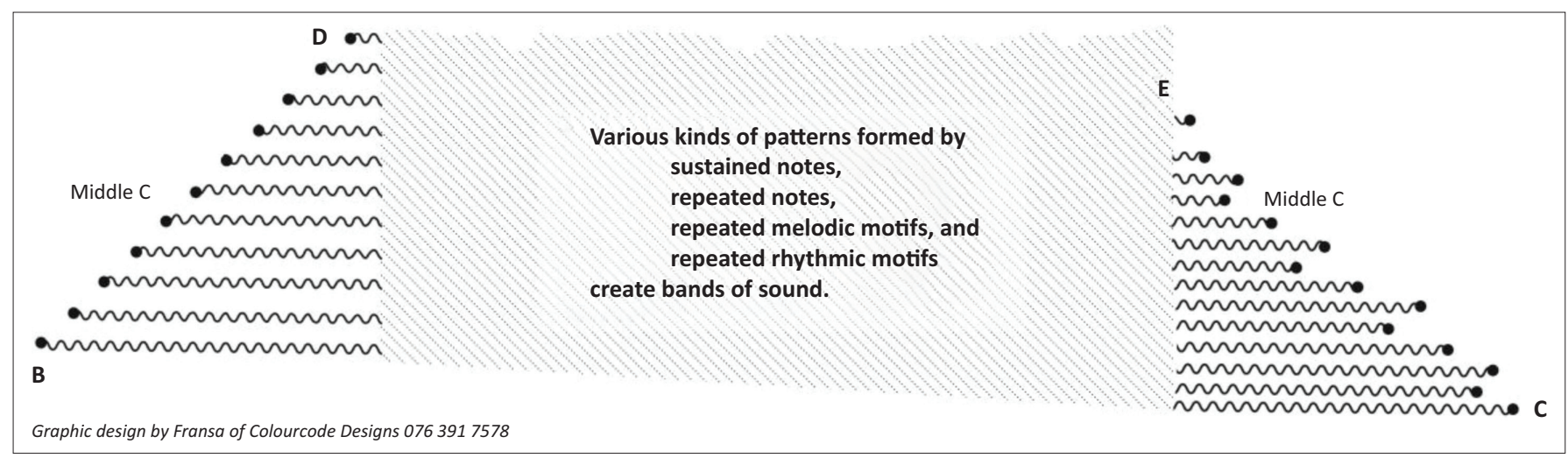

Source: Fransa Vorster (2015)

FIGURE 9: Graphic representation of Architectura.

the mountain. The effect of the ascending slope is created by 11 entries of the Alabama 8-bar phrase played by members of the string section, every entry being a fourth higher than the previous one. Every entry is repeated until the intensity of the staggered entries is relaxed to create a kind of indent that leads to the middle section.

In bar 115 a thick sound band that covers 4 and a half octaves introduces the middle section of the three-part structure. Here the effect of stasis is the result when various patterns of sustained notes, repeated notes and repeated motifs are combined asynchronically to create bands of sound. At the climax in bar 285, preceded by an increase in density and dynamics, the first trumpet plays the Alabama phrase. Here the score shows 22 lines of thematic material because all the stringed instruments start at various points of the 8-bar Alabama phrase to repeat the phrase until the end of the piece. Beginning on E (bar 292), the first violin introduces the downward slope of the gable with an entry of the Alabama phrase in C major. In Figure 9 the right-hand bullets portray the downward slope of the gable or mountain side. Each bullet represents the final note of the repeated 8-bar phrase, because after that note has been reached, that specific instrument is silent for the rest of the piece. The last four entries are again played in the lower register of the double basses. 
It must have been the first impression of the ascending slope that reminded me of the Dutch gable that features so prominently in the buildings of the Western Cape. So to conclude the discussion of Architectura, I would like to include two versions of the Dutch gable. The waviness in the outline of the gable in Baroque style (Figure 10) shows Rococo influence and the gable of the school at Noordhoek (Figure 11) is a rare example of a stepped gable, a more accurate visual resemblance of the staggered entries of Architectura.

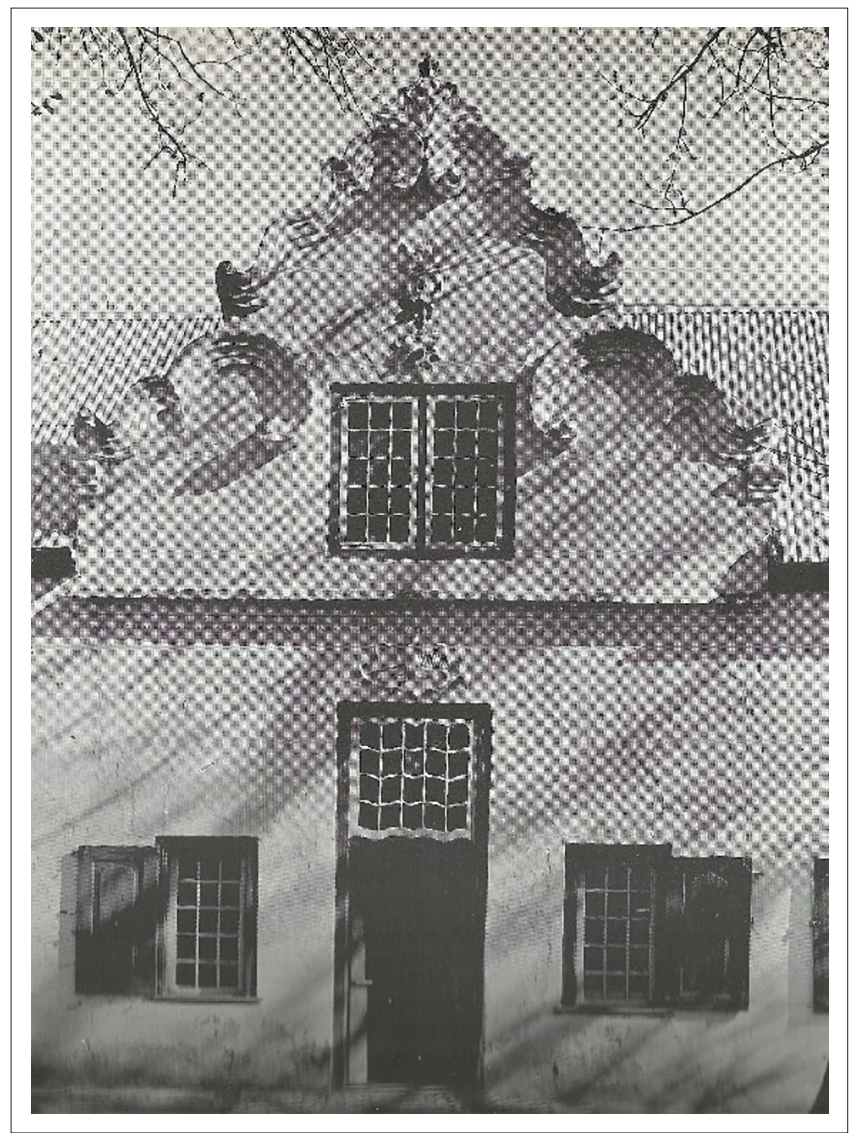

Source: Arthur Elliott (Fransen 1969, Fig. 74)

FIGURE 10: Back of Ida's Valley, Stellenbosch.

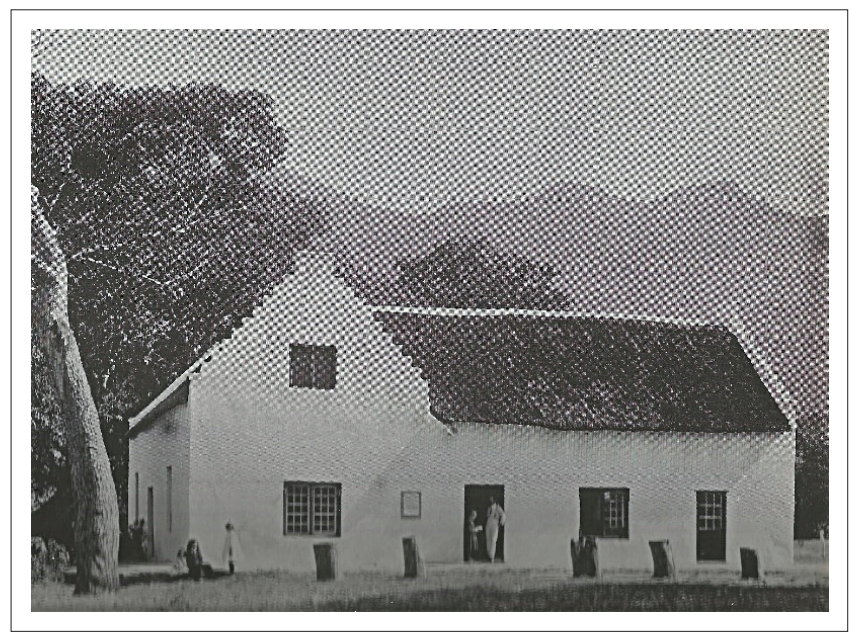

Source: Arthur Elliott

FIGURE 11: School at Noordhoek.
But whichever picture the music evokes in the listener's mind, in Architectura a true South African story from the distant past combines with a visual image that represents a specific static space, fusing time and space by means of musical expression (listen to Architectura on YouTube at https://youtu.be/uVzs5gfvGWg).

\section{Fusing the past and the present through music}

Roosenschoon's Menorah for orchestra (2005) fuses time and space as elements of Schubert's music merge with the musical representation of the structure of the candelabra to signify philosophical ideas. On the one hand, this work not only links with the musical past but also with the distant past of the composer's ancestors and, on the other hand, it also resonates with sound effects of his physical space, that is, sound effects also associated with Africa, to arrive at signification on a metaphysical level.

He ascribes his interest in the Kabbalah and the menorah to his fascination with his Jewish connections in the distant past. ${ }^{9}$ According to a certain Roosenschoon in the Netherlands, where the composer was born, the surname is of Swedish origin (Rosensen); from there it travelled to Germany (Rosenschön) and after that immigrants took the surname to the Netherlands (personal communication, March 1, 2013). In a number of compositions Roosenschoon uses well-known motivic material from what are traditionally known as the Baroque, the Classical and the Romantic eras. Schubert's (1817) An die Musik and his incomplete eighth symphony are the inspiration for Menorah.

The layered musical texture of Menorah was influenced by the composer's involvement with the Chopi and their participation in the performance of Timbila: ${ }^{10}$

When one compares the xylophone music of Timbila (1985) with, for example, the Meno Mosso section (beginning at b. 51) from Menorah, the similarities between the sound complexes should, in my opinion, illustrate the ... approach that I developed towards an assimilation of elements from African music. (personal communication, March 1, 2013)

The seven sections resemble the menorah's arch form on macro level:

the first three gathering momentum as they unfold, arriving in
the middle, the focal point of the work, where a very lyrical
theme slowly evolves, and strengthening the idea of cycles even
further. From there the work moves back, through three sections
once again, to its origin - this path being different from the one it
followed to the centre, yet having some resemblances to it.
(Roosenschoon 2013)

Musical space is filled with a seven note musical figure that also symbolises the seven arms of the menorah. This pattern A-B-C-A-G-E-F, which occurs throughout the work, relates to the opening theme of Schubert's Unfinished symphony 9.Roosenschoon's father told him about his Jewish ancestry.

10.For a discussion of Timbila, see Spies (2014b). Listen to this work on YouTube at http://youtu.be/ARymzJV4mqk 


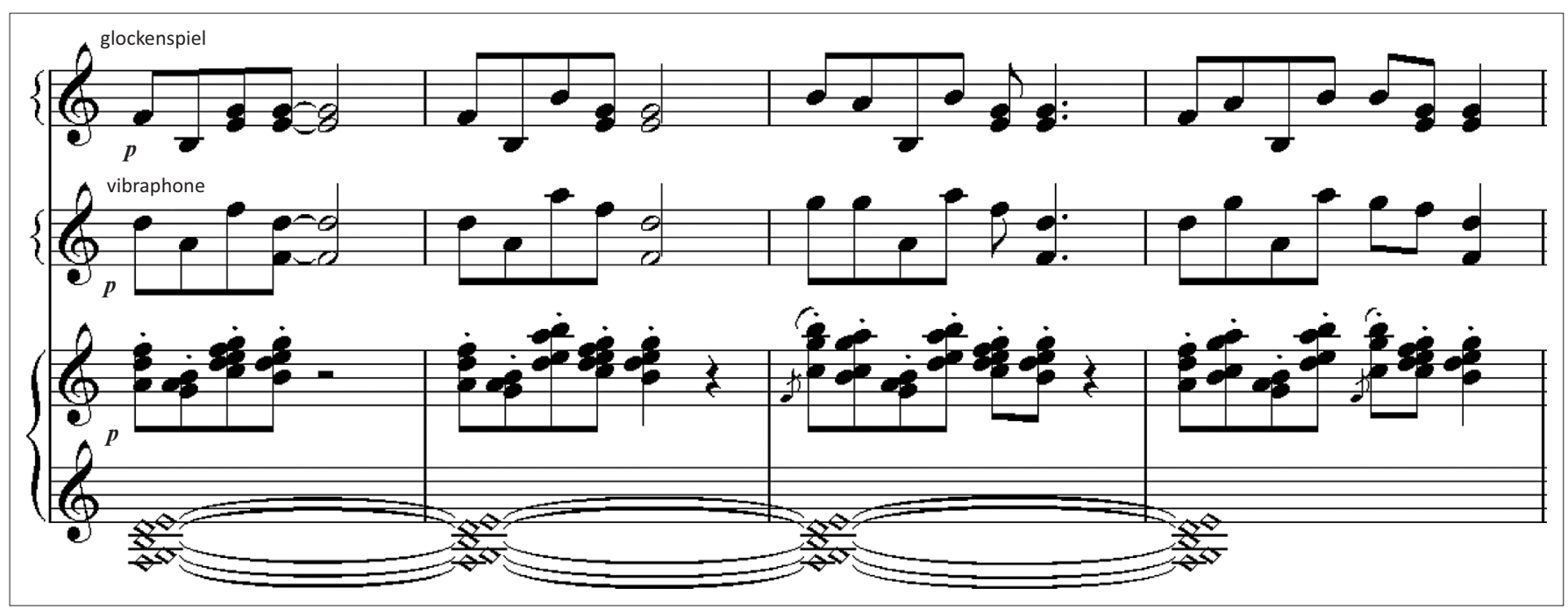

Source: Roosenschoon (2005)

FIGURE 12: Menorah, bars 11-14.

(Roosenschoon 2006). The number 7 also plays an important role in the fashioning of the music as it proceeds through space: seven notes from the opening theme are rearranged seven times to form seven horizontal lines which serve either as the top, middle or bottom line onto which the composer attaches vertical sonorities. The introduction also establishes the importance of the number 7 through the way in which a motif expands systematically to seven impulses per bar (see Figure 12).

Prominent melodic motifs in Schubert's lied An die Musik, provide the basis for connecting Roosenschoon's music with metaphysical ideas. Because these motifs are linked with words, it facilitates access to understanding on a deeper level of signification.

A free English translation of Franz von Schober's German poem is shown in Box 1. ${ }^{11}$

The downward leap of a sixth that points to Schubert's An die Musik plays an important role in Roosenschoon's composition - its first motif marked $p$ espressivo is borrowed from the beginning of Schubert's lied more specifically the interval that accompanies 'holde Kunst' (see Figures 13 and 14).

At the end of the first verse of Schubert's An die Musik the descending minor sixth appears against 'bess' $r e^{\prime}$ and 'Welt' [better, world]. This interval also accompanies 'Kunst' and 'danke' at the end of the second and final verse, marked with slurs at the end of Figure 14 [art, thank you]. The words 'Kunst, ich danke (dir!)' also connect the leap C-E with G-B through ' $i c h$ ' [I, the singer or musician] to form a three-note motif (C-E-G) that appears at the beginning of Menorah (first motif in Figure 13) (listen to Menorah on YouTube at https:/ / youtu.be/2t1vOFSDMRs).

Although the menorah is normally associated with Judaism, for Roosenschoon the candelabra with seven arms 'symbolises

11.https://en.wikipedia.org/wiki/An_die_Musik
Box 1: Words of An die Musik (Schubert).

\begin{tabular}{|c|c|}
\hline An die Musik & To Music \\
\hline $\begin{array}{l}\text { Du holde Kunst, in wieviel grauen } \\
\text { Stunden, }\end{array}$ & $\begin{array}{l}\text { You, lovely art, in how many grey } \\
\text { hours, }\end{array}$ \\
\hline $\begin{array}{l}\text { Wo mich des Lebens wilder Kreis } \\
\text { umstrickt, }\end{array}$ & $\begin{array}{l}\text { When life's mad tumult wraps around } \\
\text { me, }\end{array}$ \\
\hline $\begin{array}{l}\text { Hast du mein Herz zu warmer Lieb' } \\
\text { entzunden, }\end{array}$ & $\begin{array}{l}\text { Have you kindled my heart to warm } \\
\text { love, }\end{array}$ \\
\hline Hast mich eine beßre Welt entrückt, & $\begin{array}{l}\text { Have you transported me into a better } \\
\text { world, }\end{array}$ \\
\hline In eine beßre Welt entrückt! & Transported into a better world! \\
\hline $\begin{array}{l}\text { Oft hat ein Seufzer, deiner Harf' } \\
\text { entflossen, }\end{array}$ & $\begin{array}{l}\text { Often has a sigh flowing out from your } \\
\text { harp, }\end{array}$ \\
\hline Ein süßer, heiliger Akkord von dir, & A sweet, divine harmony from you, \\
\hline $\begin{array}{l}\text { Den Himmel beßrer Zeiten mir } \\
\text { erschlossen, }\end{array}$ & $\begin{array}{l}\text { Unlocked to me the heaven of better } \\
\text { times, }\end{array}$ \\
\hline Du holde Kunst, ich danke dir dafür! & You, lovely Art, I thank you for it! \\
\hline Du holde Kunst, ich danke dir! & You, lovely art, I thank you! \\
\hline
\end{tabular}

Source: Schubert (1817)

purity, harmony and the perfection of heaven and earth' (Roosenschoon 2013). By linking with the specific phrase of Schubert's song, Menorah may be regarded as a homage to music and a demonstration in sound of the inner bond between the composer and his art, music, as well as the belief in music's potential to help create a better world:

Artists are like discoverers - what they innovate should, at least, be important to themselves, and to their development. If their work enlightens our experience of being in a spiritual sense, and in the lives we live in society, then this calls for a celebration. (Roosenschoon 2013)

\section{Conclusion}

This article showed how various ways in which musical time fuses with space, be it cultural, musical, social or historical space, can speak directly to listeners through their senses. Finally, the discussion of Menorah also showed that music, when aided by the words in Schubert's An die Musik, has the ability to express abstract ideas on a metaphysical level. In the absence of a constative dimension, ${ }^{12}$ musical expression here relies on Schubert's 12.Constative utterances express facts and true or false statements. 


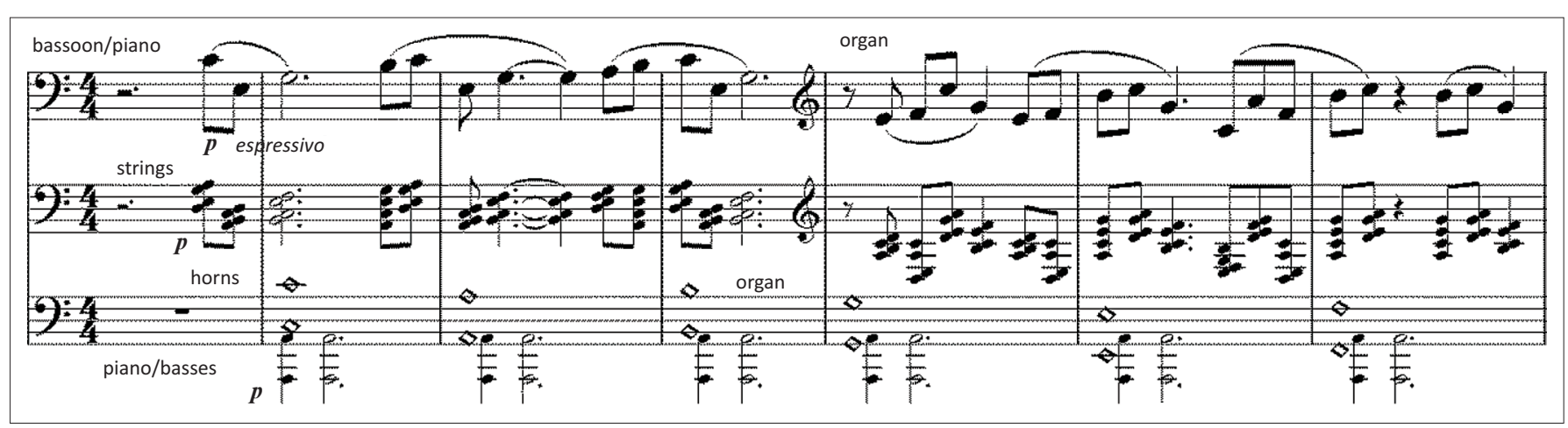

Source: Roosenschoon (2005)

FIGURE 13: Roosenschoon, Menorah, bars 1-7.

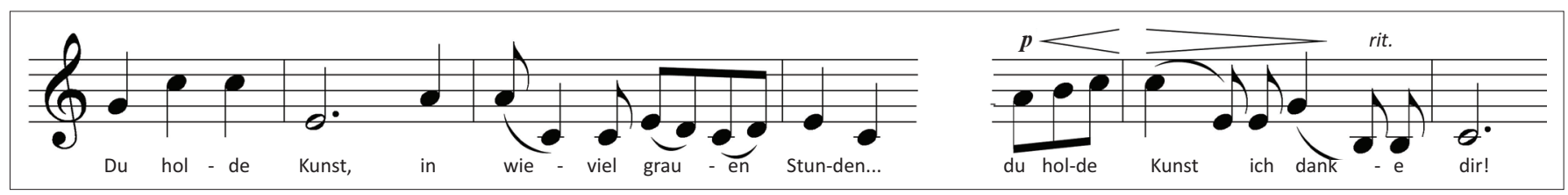

Source: Schubert (1817)

FIGURE 14: Schubert, An die Musik, beginning and end.

motifs to emphasise the potential of music as an art that helps to create a better life.

\section{Acknowledgement}

I would like to thank Hans Roosenschoon for putting at my disposal recordings of his music, scores, documents and correspondence.

\section{Competing interests}

I declare that I have no financial or personal relationship(s) which may have inappropriately influenced me in writing this article.

\section{References}

Bent, I.D. \& Pople, A., 2007-2016, 'Analysis', in S. Sadie (ed.), The new Grove dictionary of music and musicians, viewed 10 January 2016, from http://www. oxfordmusiconline.com

Britten, B., 1973, Death in Venice: An opera in two acts, op. 88, Faber, London.

Christensen, T., 1993, Rameau and musical thought in the Enlightenment, Cambridge University Press, Cambridge.

Clifton, T., 1983, Music as heard: A study in applied phenomenology, Yale University Press, New Haven, CT.

Du Plessis, P., 1989, 'Roosenschoon: Composer', ADA: Art, Design. Architecture 6, 42-43.

Fransen, H., 1969, Architectural beauty of the old Cape as seen by Arthur Elliott, A.A. Balkema, Cape Town.

James, C., 1986, 'Hans Roosenschoon: If music be', South African Journal of Musicology $6,109-111$.

Kassler, J.C. (ed.), 1991, Metaphor: A musical dimension, Gordon \& Breach, Sydney, pp. xi-xii.

Koopman, C. \& Davies, S., 2001, 'Musical meaning in a broader perspective', The Journal of Aesthetics and Art Criticism 59(3), 261-273.

Kramer, J.D., 1988, The time of music: New meanings, new temporalities, new listening strategies, Schirmer, New York.

Kramer, L., 1995, Classical music and postmodern knowledge, University of California Press, Berkeley, CA.

Makeba, M., Click song [Sound recording]. https://www.youtube.com/watch? $\mathrm{v}=$ onBLru8SfOK

McClary, S., 1989-1990, 'This is not a story my people tell: Musical time and space according to Laurie Anderson', Discourse 12(1), 104-128.
Morgan, R.P., 1980, 'Musical time/musical space', Critical Inquiry 6(3), 527-538. Muller, S.J.V.Z., 2002, Interview with Hans Roosenschoon, 05 December, provided by the composer.

Palmer, T., (Producer), 2012, Death in Venice: The opera by Benjamin Britten [Video recording]. Excerpts from the film viewed 13 September 2016, from https://www. youtube.com/watch?v=gOqGcTRwzQw

Roosenschoon, H., 1978, Makietie [Sound recording]. https://youtu.be/dIEdZOvJckg Roosenschoon, H., 1983, Anagram [Sound recording]. https://youtu.be/4_laCjIBJJc Roosenschoon, H., 1984, If music be [Sound recording]. https://youtu.be/WJNfjyST-vU Roosenschoon, H., 1985, Timbila [Sound recording]. http://youtu.be/ARymzJV4mqk

Roosenschoon, H., 1986a, Architectura: a soundscape of Cape Town [Sound recording]. https://youtu.be/uVzs5gfvGWg

Roosenschoon, H., 1986b, 'If music be - An introduction by the composer', South African Journal of Musicology 6, 109-110.

Roosenschoon, H., 2005, Menorah [Sound recording]. https://youtu.be/2t1vOFSDMRs Roosenschoon, H., 2006, Programme notes to the performance of Menorah by the JPO on 22 and 23 March.

Roosenschoon, H., 2009, 'Between heaven and earth: Cultural diversity in the music of Hans Roosenschoon', keynote address presented the conference Music and Migration organised by the New Zealand Musicological Society, University of Canterbury, Christchurch.

Roosenschoon, H., 2013, Hans Roosenschoon homepage, viewed 28 January 2013, from http://www.roosenschoon.co.za/

Roosenschoon, H., 2015, Lecture notes.

Schubert, F., 1817, An die Musik, op. 88, D547, viewed n.d., from https://en.wikipedia. org/wiki/An_die_Musik

Spies, B.M., 1994, 'Oppervlakkonstrukte as sleutel tot dieperliggende strukturele verhoudings: 'n huldeblyk aan Witold Lutosławski (1913 1994)', Suid-Afrikaanse Tydskrif vir Musiekwetenskap 14, 49-63.

Spies, B.M., 2002, 'Representation and function of characters from Greek antiquity in Benjamin Britten's Death in Venice', Literator 23, 1-18.

Spies, B.M., 2011, 'Tematiese fisionomie skep toegang tot drie uiteenlopende 20e-eeuse komposisies' [Thematic physiognomy creates access to three divergent 20th-century compositions], LitNet Akademies (Geesteswetenskappe) 8(2), 188-209. http://www.oulitnet.co.za/akademies_geestes/pdf/LA_8_2g_spies.pdf

Spies, B.M., 2014a, 'Signification in atonal, amotivic music? - Extending the properties of actoriality in Ligeti's second string quartet', Semiotica: Journal of the International Association for Semiotic Studies 202, 321-343.

Spies, B.M., 2014b, 'Time and space - The context of Hans Roosenschoon's music', The Journal for Transdisciplinary Research in Southern Africa 10, 355-379.

Spies, B.M., 2016, 'Peter Klatzow's Words from a Broken String: Two cultures meet in the distant past', Journal of the Musical Arts in Africa, 13(1-2),32-51.

Stevens, J., 2010, Here comes the Alabama, viewed 2 April 2013, from http://www. jason-stevens.com/2010/07/here-comes-the-alabama-daar-kom-die-alabama/

Tarasti, E., 1994, A theory of musical semiotics, Indiana University Press, Bloomington. Van Rooyen, I., 2013, 'Laag op laag: talent en vernuwing', Die Burger By, 16 March, p. 3. 